\title{
The improving of effectiveness school-based enterprise: A structural equation modeling in vocational school management
}

\author{
Arie Wibowo Khurniawan', Illah Sailah², Pudji Muljono ${ }^{3}$, Bambang Indriyanto ${ }^{4}$, M. Syamsul Maarif ${ }^{5}$ \\ ${ }^{1}$ Postgraduate Program, Bogor Agricultural University, Indonesia \\ ${ }^{2,3,4,5}$ Bogor Agricultural University, Indonesia
}

\section{Article Info \\ Article history:}

Received Aug 22, 2020

Revised Dec 17, 2020

Accepted Jan 26, 2021

\section{Keywords:}

Indonesia vocational school School effectiveness

School-based enterprise

Structural equation modeling

Vocational school management

\begin{abstract}
The study aimed to investigate the influence of total quality management and school governance on school management effectiveness, whether school governance as an antecedent of total quality management and school management effectiveness. The object of research is the vocational high school with the Regional Public Service Agency status (school-based enterprise) in Indonesia. The research is a quantitative research with survey method. The sample of 533 people who are school principals, teachers, and students. It was selected by proportional stratified random sampling. The data analysis using structural equation modeling (SEM). The research finding is the total quality management has a significant influence on school management effectiveness. The mediation analysis indicates that school governance as the antecedent of total quality management and school management effectiveness. The improvement of effectiveness school-based enterprises should consider implementing total quality management and it will be increasingly by school governance application. The modeling that correlates total quality management and school governance to improved vocational school management effectiveness, especially at vocational school with Regional Public Service Agency status (school-based enterprise).
\end{abstract}

This is an open access article under the CC BY-SA license.

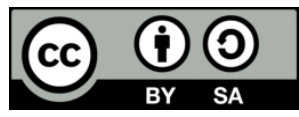

Corresponding Author:

Arie Wibowo Khurniawan

Student of Postgraduate Department

Bogor Agricultural University

Babakan, Dramaga, Bogor, West Java 16680, Indonesia

Email: arie_wibowo@apps.ipb.ac.id

\section{INTRODUCTION}

The existence of a vocational high school system in Indonesia produces many semi-skilled graduates; on the other hand, the job market has limited capacity to distribute the graduates. The development of vocational schools' development has not been in line with industry needs and has not responded to market needs. The link and match between vocational schools and industry are considered not yet to occur as a whole and is still limited. It fact has shown from the high vocational school graduates who are not getting the job properly. Central bureau of statistics (BPS) publications for 2017, 2018, 2019 unemployment rates of vocational school graduates are $9.27 \%, 8.92 \%$, and $8.63 \%$ respectively [1]. This condition shows that there are problems in school management in the aspect of compliance with vocational school industry standards.

Vocational education in Indonesia has the lowest quality index compared to other types of education. It is proven, which is only $12 \%$ of 13,929 schools that have good accreditation. It is shown that there are many problems in the schools management. Although several vocational high school in Indonesia 
has implemented a total quality management (TQM) policy in their schools following the standards required by Indonesian Government Regulation No. 19 of 2005.

The TQM philosophy is effective management for perpetual improvement, increase customer value and satisfaction, and good organizational performance [2]. The TQM concept consists of excellence, value, and worthiness of educational outcomes and experience to achieve goals, objectives, specifications, and requirements in education [3]. TQM's use as a model for improving school quality is relevant to many experiences, as investigated in private and public companies and many university organizations [4]. The implementation of TQM can be applied successfully in educational organizations, particularly in schools that focus on improving the potential of students to achieve the top level [5]. Although this model has been used for many years outside the educational environment, this modeling has been recognized by most university leaders as one of the innovative approaches to improve the performance of higher education management for university structure units [4].

School effectiveness can be reviewed through student academic achievement [6]. National exam scores in 2018-2019, the academic conditions of students, especially in vocational schools are still not satisfactory. Nationally, the average national exam scores in 2018/2019 in vocational schools are only 46.7, with the lowest score on the math test with an average of 35.26. This indicates that vocational schools need to improve the effectiveness of school management, especially related to student academics.

This gap indicates the ineffectiveness of management in school governance (SG). The application of SG principles as an essential value in school management will have a great opportunity to improve school performances and the quality of education continuously. SG emerged as an effort to improve quality to produce a solid school organization governance performance. SG has a synergy with TQM because the company's management style can be adjusted to the concept of quality management if it is strengthened by the principles used to create good governance [7]. Governance has a direct effect on performance, and of course, governance principles are also very influential in shaping good governance [8].

The focus of the Indonesian government at this time is on improving the quality of vocational schools. This is evidenced by the Presidential Instruction issued on Revitalization of Vocational Schools to improve the quality and competitiveness of Indonesian human resources at Presidential Instruction Number 9 of 2016. The existence of organizational transformation of State Vocational Schools into a form of Regional Public Service Agency (school-based enterprise) the efforts to improve the quality of vocational schools as mandated in the Minister of Domestic Affairs Regulation No. 79 of 2018. Based on this mandated, the provincial government as the person in charge of vocational school is encouraged to change the state vocational school's status to a vocational school-based enterprise. The aim of the transformation of vocational schools organizations into a vocational school-based enterprise is to provide flexibility in vocational schools financial management based on productivity and economic principles and the application of sound business practices to be able to maximize cooperation with industry to improve the competency of vocational schools students.

The school was initially only an extension of the central government to the school management to organize educational politics. This centralized education governance system does not give authority to schools to develop the organization, curriculum, school management, learning, resources, and community participation. Nowadays, this centralized education system right now has a problem. This system is considered not to have a positive effect on improving the quality of the education. Therefore, Law Number 32 of 2004 said that the government should give every region authority to take care of the communities' interests. This authority indirectly encourages changes in the management of education. The transfer of power and authority to the school level is primarily aimed at empowering school stakeholders in school decision-making, which was previously only carried out by the central, provincial, or district governments. The transfer of authority to schools aimed at empowering school stakeholders in determining policies was previously only carried out by the central, provincial or district governments [9-12]. This decentralized system assumes that school stakeholders will be more concerned if about the reality that exists in schools, and that their decisions will be more appropriate [13].

Education policy from centralistic to decentralize has not yet run maximally and thoroughly for this implementation. Whereas schools have been given authority and discretion for regulate their school management. Its has long been launched in line with the implementation's regional autonomy, where the Ministry of Education and Culture launched school-based management (School Governance) as a new paradigm in school operations to change school management that used to be center-based. Even though the government policy has given schools to manage their schools, but there are some education variables are still regulated by the central government, among others: curriculum, exam implementation, and other education personnel. This causes the school to be less optimal in utilizing the policy. Principals must be able to innovate in developing their schools and become policymakers at school. Even though the change in direction of education that was previously centralized to decentralized is very good to improve school 
management. Many research results show that improving the quality of teaching and learning is highly dependent on the quality of leadership carried out by the principal. These factors can be used to debate stronger control over management schools.

Schools were initially only to extend their hands from the central government to school administrators for political education. This centralized education governance system will not authorize schools to develop an organization, curriculum, school management, learning, resources with community participation. Law Number 32 of 2004 explained that the government is only committed to the regions in implementing the people's interests of the people's aspirations so that the education system must be considered because it focuses on improving the quality of education. This authority does not directly provide a spirit of change in the administration of education. Decisions made previously are only carried out by central, provincial, or district government authorities [9-12]. This decentralized system assumes that schools will pay more attention to them, must increase understanding of the existing schools in schools, and how their decisions will make them more appropriate. The decentralized system will assume that a school will increase understanding of the school and how their decisions will make it more appropriate [13].

The novelty of this study is the design of strategies for increasing the effectiveness of SMKs through the implementation of school governance, both in terms of top-level (school governance) and management in terms of operational (total quality management). The modeling that connects SG and TQM to the effectiveness of schools applied to vocational school as shown in Figure 1, especially in vocational schoolbased enterprises, has never been proposed before. Besides, the analysis of factors that are valid and can measure the effectiveness of vocational school-based enterprises based on the application of integrated school governance and quality management that have not been produced in previous studies are also discussed in this study. On the other hand, this research proposes a new indicator that is used to build the effectiveness of school management variables, which are indicators of the flexibility of school budget management. This indicator is proposed as a novelty because researchers believe that if schools are given flexibility in budget management they will be able to create effectiveness in school management.

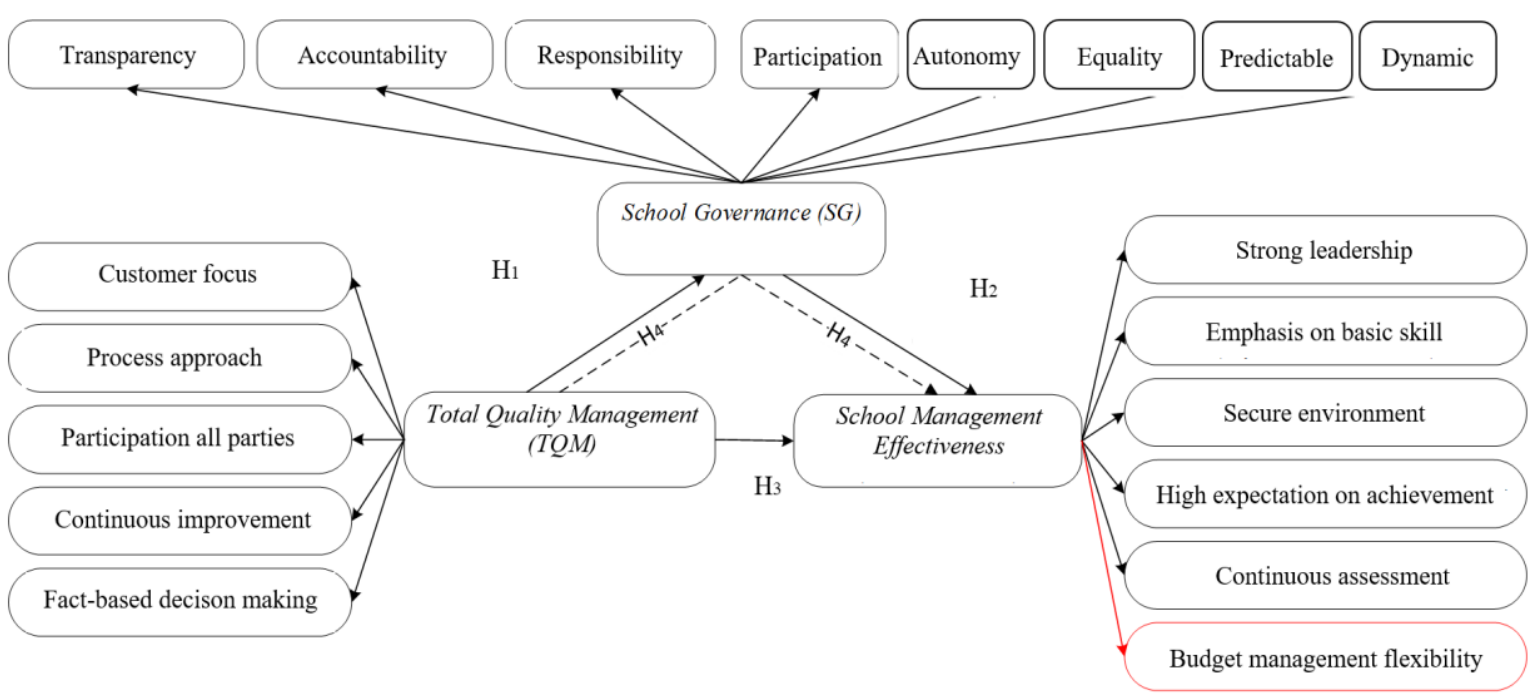

Figure 1. Vocational school management effectiveness model

Total quality management (TQM) is a study of holistic leadership practices or a holistic approach to school improvement programs. The principal's implementation of TQM practices is considered very good, which means that the principal can provide a culture that involves quality in all school operations' aspect. Ralph, et al. [14] show that TQM is part of excellence because it can satisfy stakeholders; meet the specific needs of end-users; and meet the needs of members of the organization. Leaders are those who continually work with clients to guide and influence in achieving goals [15]. The principal as a leader is an individual who has a role to guide and influence elements of the school to achieve school goals. This might mean that leaders must have an ongoing desire for improvement by expressing their cooperation to achieve common goals. Senge [16] said that quality-oriented schools believe always make an improvement to meet stakeholder expectations. The above results can also be related to what Kerzner showed that what distinguishes TQM from management theory and other improvements is stakeholder satisfaction [17]. 
School governance (SG) refers implementation of decentralized decision-making is decision making from the central, regional and school division levels. The status of SG implementation by school principals is at a "progressive" level, which indicates an increase in resource mobilization and maximum effort from schools. SG aims to empower school principals to be able to better coordinate teachers and students; support the provision of quality education services; building partnerships with communities and industry, and instituting a process of school improvement that is sustainable and participatory. SG is the main tool for the continuous improvement of schools [18]. Furthermore, according to Grauwe [19], SG is an effective management system and improving the quality of education. SG formed a community partnership to foster good relationships between educators, students, families and the community as a whole for better school performance.

Fullan [20] and Fredriksson [21] state that pedagogical leadership is important advocacy for school principals [20, 21]. The education administrator must accept and implement this role so that the school is managed effectively. The contribution of an administrations' school can improve a person's attitude. Mukhopadhyay emphasizes that development by principals aims to ensure the transformation and continuous learning of students towards a holistic development [22].

The relationship between TQM and SG revealed that the principal's role in implementing SG was very important in staff development, physical development, and student development in terms of improving school quality [23]. This shows that student development is highly dependent on the leaders' performance in particular and the school system in general. TQM practices related with leadership, focus on clients, stakeholders, commitment to change, and continuous improvement. School leadership and school improvement have a relationship and engagement with data-based decision making, professional learning, and systems focus. Accordingly, the following hypothesis was formulated:

H1 : "Total Quality Management is positively related to School Governance."

Implementing educational reforms offered to schools by giving full authority to the schools resulted in a new management theory. This system reverses the management pyramid, where responsibilities related to school management are no longer delegated to central or regional state authorities but are given to the staff of educational institutions. Power and authority at the school level are aimed at the members of the school stakeholders that have been made by the government [9-11]. This is based on the decision making that can be done quickly so that a more effective mechanism is created while encouraging a new spirit of performance for the school principal as the school manager. The delegation of authority related to decision making from the government to the school level has created a more democratic model of school administration bureaucracy [10].

The relationship between SG and the effectiveness of school management is still a heated debate. Cheng and Mok [24] argue that SG does not contribute to improving student learning and achievement. To produce improvements, additional interventions from SG are needed. Nir and Hameiri [25] also found that it was difficult to reach firm conclusions about SG's contribution to improving student learning as well as to increase school effectiveness. Robinson, et al. [26], which examined the decentralization of organizational decision makings' the four components, concluded that there was no link between teaching and learning, teaching design, human resource management, and physical resource management, to school effectiveness. School authorities will provide several opportunities to make sound and flexible decisions in achieving significant learning outcomes [27]. Bergman [28] also said that the reputation of the School will increase excellence, creativity, eager involvement, and staff dedication as a result of SG.

Many countries believe that decentralization increases school effectiveness because this school leadership system will be assigned a greater responsibility. The best strategy for implementing decentralized education reform in the United States and elsewhere is School Governance [29-31]. SG will offer authority to schools and provide decision-making decisions [31]. The public support's growth for SG is based on the argument that if school autonomy and flexibility would increase, the design and implementation of school programs can be implemented better, faster and following the special needs of children [32] and that this is the most efficient way to improving school practices and meeting the expectations of diverse stakeholders in a changing environment [24, 29]. This participation allows people and organizations with unique goals to take responsibility for their destiny [33]. An experimental educational reform process that aims to improve education in schools in various countries $[34,35]$. SG will involve the use of participatory management and school autonomy related to school capacity [36, 37].

Odden and Wohlstetter [38] identify conditions that drive increased school effectiveness through SG. They found that stakeholders in schools where SG had been implemented effectively could improve school performance with authority over the budget, personnel, and curriculum. Successful schools in implementing SG by the authorities and authorities in implementing changes directly related to teaching and learning practices. Decisions about student performance, satisfaction from parents, school resources, and systematic and creative communication between parents will be effective when professional development, training to recommend, management, and problem skills of teachers and other stakeholders provide important 
information. Rodriguez and Slate [39] emphasized that with flexibility, proper autonomy in carrying out school functions, SG can maximize school effectiveness and create conditions that must be met to achieve various school goals.

Caldwell [40], who examined the SG sample in Australia, found that schools that used the SG component would experience a significant teaching and learning process. This research is also supported by research [34, 40, 41], which states that the decentralization of reforms provides significant improvements, both in terms of improving education and learning achievement and increasing school effectiveness. SG is considered capable of improving the quality of education, providing a healthier learning and teaching environment that can ultimately improve student achievement [40, 42-46]. Lo, et al. [47] suggested that school autonomy positively affects school governance and management, school-based curriculum, teacher work, and student learning if there is firm leadership, comprehensive professional development, and adequate school climate. In conclusion, Leithwood, et al. [48] found that out of 11 scientific journals that reported SG's effect on school effectiveness, five of 11 scientific journals reported negative or neutral effects, and six studies reported positive effects. Hence, the following hypotheses:

H2 : "School Governance is positively related to School Management Effectiveness."

Each school certainly has its picture related to effective schools for improving quality in schools. The quality of education leads to a prospective future, so insights about the quality index and virtual implementation need to be made to categories in various strata of education, for example, schools, universities, education management, and staff. Quality must be brought to the system in all aspects from infrastructure to classroom teaching, professional development, and scientific temperament development. To compete in a global context, educational institutions especially schools must promote quality education. All educational institutions must provide sophisticated infrastructure, quality teaching staff, and quality management through the implementation of TQM. Not only government-assisted institutions but educational institutions that are privately managed must be urged to adopt the TQM philosophy. TQM must be applied to other organizations for better performance [49].

There are some basic principles and tools in higher education organizations that can be applied because they have the instruments service institutions and their governance and management boards are subject to academic mission, goals, and strategies. TQM can be applied successfully in an educational organization, especially in schools that focus on increasing the potential of students to the highest level [5]. The principles carried out by TQM have wide applications in educational organizations and provide the results expected by the organization. This ongoing process has created an environment of unity, change and trust that is carried out by the development of the school [50].

TQM is a managerial instrument for solving problems related to services and tactics in the academic industry and can be in line with education industry standards [51, 52]. The same thing was conveyed also by Koch and Fisher [53]. According to them, TQM were relevant to education, especially higher education, because TQM is a process-oriented approach designed to increase productivity, reduce costs, and improve quality. Deming [54] states that TQMs' adoption will help educational institutions to maintain competitiveness, eliminate inefficiencies in organizations, help concentrate on market needs, achieve high performance in all fields, and meet the needs of all stakeholders. This is in line with Tribus [55] which states that education can be improved through quality management TQM is able to improve the educational process, making the educational environment motivational, improving the education curriculum, increasing the speed of training services, and reducing costs [56].

TQM is defined a set of tools used to improve the quality of the company [57]. This shows that TQM has a flexible nature that can be adjusted according to the existing situation and applies to any organization [2]. Although TQM which is usually only developed in a manufacturing environment now also applies to schools because of the benefits of this TQM [58]. This approach focuses on quality improvement programs for organizational system components in the education sector.

Sahney, et al. [3] and Sharples, et al. [59] argue that TQM can be applied in education as long as its adoption is part of a strategic planning process that has TQM as an objective and is adjusted according to a particular context. After the strategic plan has been adopted, an implementation plan needs to be prepared to facilitate the achievement of TQM objectives. Principals need to encourage the adoption and implementation of TQM philosophies that are adjusted in schools by communicating goals and policies and by modeling commitments to a quality culture [60]. Adopting TQM as a change strategy for schools does not mean that schools must seek perfection in all their products and services, but schools must strive to provide the best services $\&$ products $\&$ the best quality in unique contexts and circumstances. Therefore, quality standards are contextual and the main objective is to become a starting point for the formation of structures and procedures that will improve quality [61].

The use of TQM as a model for improving school performance is relevant to many experiences as investigated in private and public companies, and many university organizations [4]. Although this model has 
been used for many years outside the educational environment, this model has been recognized by most university leaders as an innovative approach to improving the performance of higher education management for hierarchical university structure units [4]. Evidence from many research studies shows a significant increase in terms of increased employee productivity and overall changes to advance public services provided by members of the organization to customers.

Hoyle [62] states that management theory is related to guiding practices and enables practitioners to increase organizational effectiveness. In line with this opinion, McMahon [63] adds that management theory is a practice guideline that also includes decision making and authority for increasing effectiveness. While Oakland [64] and Summers [65] revealed that TQM is one way of managing an organization as a whole to increase organizational effectiveness, flexibility, and competitiveness. This indicates a relationship between management and performance.

According to Lezotte [6], there is a significant relationship between the principles of integrated quality management and effective ecology. In the field of education, this quality management practice provides a perspective to see the problems faced by schools and as a tool to remove obstacles in creating an effective school. This human-focused approach can contribute fully to improve the educations' quality and educational organizations' improvement. Educational organizations' inputs and outputs are human, and the main actors are these humans at all levels and in all organizational processes. Human without satisfaction (both as customers and providers) will affect the effectiveness of education [66]. Therefore:

H3 : "Total Quality Management has a positive association with School Management Effectiveness."

The results of Liantos \& Pamatmat's research [23] that the implementation of TQM, in general, influences school leadership. TQM practices have a relationship with staff development and school leadership in carrying out their role in SG. This implies that the principal can provide a culture that requires quality in all aspects of school operations and a holistic approach to school improvement programs and the creation of school effectiveness. In other words, TQM plays a role in creating SG applications that can improve school performance by making those closest to service delivery (teachers, principals, and the community) more independent, more involved, and therefore more responsible for decisions taken. Plus, school management based on TQM is an effective way to improve school quality systems [67].

On the other hand, Arar and Nasra's research [68] revealed that there is a positive relationship between SG and school effectiveness. According to him, with the SG practice, the principal's decisionmaking authority, school decision-making, and the involvement of the school board could emerge to be able to create a better teaching and learning environment and student academic achievement. In line with this research, Bandur [10] and Gamage [45] suggest that SG can empower schools to develop a higher quality education process, a healthier teaching and learning environment, stronger parent and community involvement, and stronger student outcomes. Better as an indicator of effective schools [10, 45]. So, it can be concluded that the application of TQM in schools influences the leadership of principals, which in turn can maximize the role of the principal in carrying out school governance to achieve goals and maximize school effectiveness. Therefore, we hypothesize:

H4 : "School Governance mediates the relationship between Total Quality Management and School Management Effectiveness."

\section{RESEARCH METHOD}

\subsection{Research design}

This study employed quantitative approach. It is a data-based approach where in the conclusions are made based on statistical methods. Data collection using survey methods through questionnaires. This research was conducted in the provinces of East Java and Jakarta as two provinces in Indonesia that have implemented the Regional Public Service Agency (school-based enterprise) in Indonesia Vocational High School. This research was conducted in March 2020 to March 2021.

\subsection{Population and sample}

The study population was the vocational school with the Regional Public Service Agency status in Indonesia as the population in this study. Unit population members in this study were 43,142 people who were principals, teachers, and students. The sample size is calculated using the Slovin formula. Each vocational school is heterogeneous because it has different characteristics for each school, so stratified random sampling is used by making each vocational school as strata. This sampling technique considers the proportion of the sample from each stratum [69]. Then, the proportional stratified random sampling technique is used so that the distribution of the questionnaire is proportional to the population for each school. The research sample described in Table 1. 
Table 1. Vocational school list and sample size

\begin{tabular}{|c|c|c|c|}
\hline No & Vocational high school & Population & Sample size \\
\hline 1 & SMKN 1 Surabaya & 2,986 & 27 \\
\hline 2 & SMKN 5 Surabaya & 3,054 & 28 \\
\hline 3 & SMKN 6 Surabaya & 2,534 & 23 \\
\hline 4 & SMKN 1 Buduran Sidoarjo & 1,405 & 13 \\
\hline 5 & SMKN 3 Buduran Sidoarjo & 1,547 & 14 \\
\hline 6 & SMKN 2 Malang & 2,003 & 18 \\
\hline 7 & SMKN 4 Malang & 3,056 & 28 \\
\hline 8 & SMKN 11 Malang & 1,927 & 18 \\
\hline 9 & SMKN 1 Singosari & 2,266 & 21 \\
\hline 10 & SMKN 1 Panji Situbondo & 2,344 & 22 \\
\hline 11 & SMKN 1 Surabaya & 2,986 & 36 \\
\hline 12 & SMKN 5 Surabaya & 3,054 & 38 \\
\hline 13 & SMKN 6 Surabaya & 2,534 & 31 \\
\hline 14 & SMKN 1 Buduran Sidoarjo & 1,405 & 17 \\
\hline 15 & SMKN 3 Buduran Sidoarjo & 1,547 & 19 \\
\hline 16 & SMKN 2 Malang & 2,003 & 24 \\
\hline 17 & SMKN 4 Malang & 3,056 & 38 \\
\hline 18 & SMKN 11 Malang & 1,927 & 24 \\
\hline 19 & SMKN 1 Singosari & 2,266 & 28 \\
\hline 10 & SMKN 1 Panji Situbondo & 2,344 & 30 \\
\hline 21 & SMKN 1 Kalipuro & 260 & 3 \\
\hline 22 & SMKN 2 Bondowoso & 596 & 7 \\
\hline 23 & SMKN 5 Jember & 2,689 & 34 \\
\hline 24 & SMKN 3 Madiun & 1,416 & 17 \\
\hline 25 & SMKN 1 Pacitan & 1,634 & 20 \\
\hline 26 & UPTSMKN 2 Pasuruan & 1,483 & 19 \\
\hline 27 & SMKN 3 Boyolangu & 2,242 & 28 \\
\hline 28 & SMKN 1 Glagah & 2,121 & 26 \\
\hline 29 & SMKN PP Negeri 1 Tegalampel & 739 & 9 \\
\hline 30 & SMKN 1 Jenangan & 2,173 & 27 \\
\hline 31 & SMKN 57 Jakarta & 1,273 & 16 \\
\hline 32 & SMKN 27 Jakarta & 1,400 & 17 \\
\hline 33 & SMKN 36 Jakarta & 854 & 11 \\
\hline 34 & SMKN 26 Jakarta & 570 & 7 \\
\hline \multirow[t]{2}{*}{35} & SMKN 63 Jakarta & 570 & 7 \\
\hline & Total of respondents & 43,142 & 533 \\
\hline
\end{tabular}

\subsection{Variable measurements}

Total quality management (TQM) was a latent exogenous variable. TQM is measured by five indicators adopted from Bergman \& Klefsjö [70]; Kennerfalk [71]. School governance (SG) is an exogenous latent and intervening variable. The SG measurements use eight principles taken from Hénard \& Mitterle [72]; ISSA [73]; Quyen [74]. School Management Effectiveness is an endogenous latent variable. It is measured by six indicators from Hoy [18]; Verma \& Chabra [75]; Scheereens [76]. All items of research instruments were measured using a 5-point Likert Scale, ranging from 1 (strongly disagree) to 5 (strongly agree). The variables fefinition and indicators shown in Table 2. 
Table 2. Variables definition and indicators

\begin{tabular}{|c|c|c|}
\hline Variables & Definition & Indicators \\
\hline $\begin{array}{c}\text { School } \\
\text { governance }\end{array}$ & $\begin{array}{l}\text { The right of school autonomy to implement school } \\
\text { management, especially in the management of } \\
\text { human resources, financial and material resources } \\
\text { available at school }[19,29,40] \text {. }\end{array}$ & $\begin{array}{ll}\text { 1. } & \text { Transparency } \\
\text { 2. } & \text { Accountability } \\
\text { 3. } & \text { Responsibility } \\
\text { 4. } & \text { Participation } \\
\text { 5. } & \text { Autonomy } \\
\text { 6. } & \text { Equality } \\
\text { 7. } & \text { Predictable } \\
\text { 8. } & \text { Dynamic } \\
\text { Henard \& Mitterle [72]; ISSA [73]; Quyen [74]. }\end{array}$ \\
\hline $\begin{array}{l}\text { Total quality } \\
\text { management }\end{array}$ & $\begin{array}{l}\text { A management strategy system to improve } \\
\text { productivity and quality, by responding } \\
\text { appropriately to every change. It aims to satisfy } \\
\text { students, parents, and the government }[57,77,78] \text {. }\end{array}$ & $\begin{array}{l}\text { 1. } \quad \text { Customer focus } \\
\text { 2. } \quad \text { Process approach } \\
\text { 3. } \quad \text { Participation in all parties } \\
\text { 4. } \quad \text { Continuous improvement } \\
\text { 5. Fact-based decision making. } \\
\text { Bergman \& Klefsjö [70]; Kennerfalk [71]. }\end{array}$ \\
\hline $\begin{array}{l}\text { School } \\
\text { management } \\
\text { effectiveness }\end{array}$ & $\begin{array}{l}\text { The ability of schools to provide quality services } \\
\text { for students with a targeted period [76]. }\end{array}$ & $\begin{array}{l}\text { 1. Strong leadership } \\
\text { 2. Emphasis on basic skill } \\
\text { 3. Secure environment } \\
\text { 4. The high expectation for achievement } \\
\text { 5. Continuous assessment } \\
\text { 6. Budget management flexibility } \\
\text { Hoy [18]; Verma \& Chabra [75]; Scheereens [76]. }\end{array}$ \\
\hline
\end{tabular}

Confirmatory factor analysis is used to test the validity of eight School Governance indicators, five indicators of Total Quality Management, and six indicators of School Management Effectiveness. Confirmatory Factor Analysis is an adequate technique in testing the functioning of empirical constructs (factors) in a structural model [79]. The result of validity and reliability testing described in Table 3.

The results of the Confirmatory Factor Analysis show the value of loading factors of all School Governance indicators, Total Quality Management, and School Management Effectiveness variables have values greater than 0.50 . Therefore it can be concluded that all indicators can explain the construct so that it is feasible to use for the next stage. Cronbach's alpha is a convenient test used to estimate reliability. Testing the reliability of the construct obtained Cronbach's alpha coefficient 0.936, 0.926, and 0.928 for school governance, total quality management, and school management effectiveness respectively.

Table 3. Validity and reliability testing

\begin{tabular}{|c|c|c|c|c|}
\hline Item & Indicators & $\begin{array}{c}\text { School } \\
\text { governance }\end{array}$ & $\begin{array}{l}\text { Total quality } \\
\text { management }\end{array}$ & $\begin{array}{l}\text { School management } \\
\text { effectiveness }\end{array}$ \\
\hline $\mathrm{X} 1.1$ & Transparency & 0.733 & & \\
\hline $\mathrm{X} 1.2$ & Accountability & 0.813 & & \\
\hline $\mathrm{X} 1.3$ & Responsibility & 0.679 & & \\
\hline $\mathrm{X} 1.4$ & Participation & 0.823 & & \\
\hline $\mathrm{X} 1.5$ & Autonomy & 0.836 & & \\
\hline $\mathrm{X} 1.6$ & Equality & 0.865 & & \\
\hline $\mathrm{X} 1.7$ & Predictable & 0.875 & & \\
\hline $\mathrm{X} 1.8$ & Dynamic & 0.829 & & \\
\hline $\mathrm{X} 2.1$ & Customer focus & & 0.793 & \\
\hline $\mathrm{X} 2.2$ & Process approach & & 0.839 & \\
\hline $\mathrm{X} 2.3$ & Participation in all parties & & 0.870 & \\
\hline $\mathrm{X} 2.4$ & Continuous improvement & & 0.851 & \\
\hline $\mathrm{X} 2.5$ & Fact-based decision making & & 0.862 & \\
\hline Y1.1 & Strong leadership & & & 0.799 \\
\hline $\mathrm{Y} 1.2$ & Emphasis on basic skill & & & 0.885 \\
\hline Y1.3 & Secure environment & & & 0.898 \\
\hline Y1.4 & The high expectation for achievement & & & 0.845 \\
\hline Y1.5 & Continuous assessment & & & 0.854 \\
\hline Y1.6 & Budget management flexibility & & & 0.799 \\
\hline \multicolumn{2}{|c|}{ Cronbach's alpha } & 0.936 & 0.926 & 0.928 \\
\hline
\end{tabular}

\subsection{Data analysis}

Hypothesis testing to test whether exogenous latent variables have a significant effect on endogenous latent variables. The test used the structural equation modeling (SEM) statistical method. The SEM is a technique to test the causality relationship in which changes in one variable against other variables are based on theory. Therefore, in developing hypotheses and modeling, theoretical studies are needed [79]. 
After building the theoretical framework model, the model is then drawn into a cross diagram so that the causality relationship between endogenous and exogenous latent variables described clearly. The relationship between latent variables or between exogenous variables and endogenous latent variables in a model is explained in the structural model. This test is carried out to find out how much the percentage of the variance of each endogenous latent variable that is explained by the exogenous latent variable in the model. It is explained by the R-squares value. Modification of the model from the results of the evaluation and interpretation of the model is done if the value of the Goodness of Fit does not meet the established standards.

\section{RESULTS AND DISCUSSION}

\subsection{Descriptive analysis}

Research respondents were 533 people who are 13 school principals, 172 teachers, and 348 students. Table 4 shows the female respondents more than male. The majority of respondents as students are $65.3 \%$.

Table 4. Demographics of respondents

\begin{tabular}{cccc}
\hline Demography & Description & Frequency & Percentage \\
\hline Gender & Female & 271 & $50.8 \%$ \\
& Male & 262 & $49.2 \%$ \\
Position & Principal & 13 & $2.4 \%$ \\
& Teacher & 172 & $32.3 \%$ \\
& Student & 348 & $65.3 \%$ \\
Education level & Junior high school & 348 & $65.3 \%$ \\
& Diploma 4 & 12 & $2.3 \%$ \\
& Undergraduate & 103 & $19.3 \%$ \\
& Master & 67 & $12.6 \%$ \\
& Doctor & 3 & $0.6 \%$ \\
\hline
\end{tabular}

\subsection{Analysis of structural equation modeling}

A preliminary data analysis was carried out, in which the accuracy of the results, the outliers, the normality, the missing values, and the multicollinearity of all variables were tested. First, a confirmatory factor analysis using AMOS 21 was carried out to verify the scales of the scales used to assess the convergent and discriminatory validity. Finally, structural equation modeling was used to test the proposed model and assess the proposed relationships between total quality management (TQM), school governance (SG), and School Management Effectiveness. Analysis of structural equation modeling is shown in Figure 2.

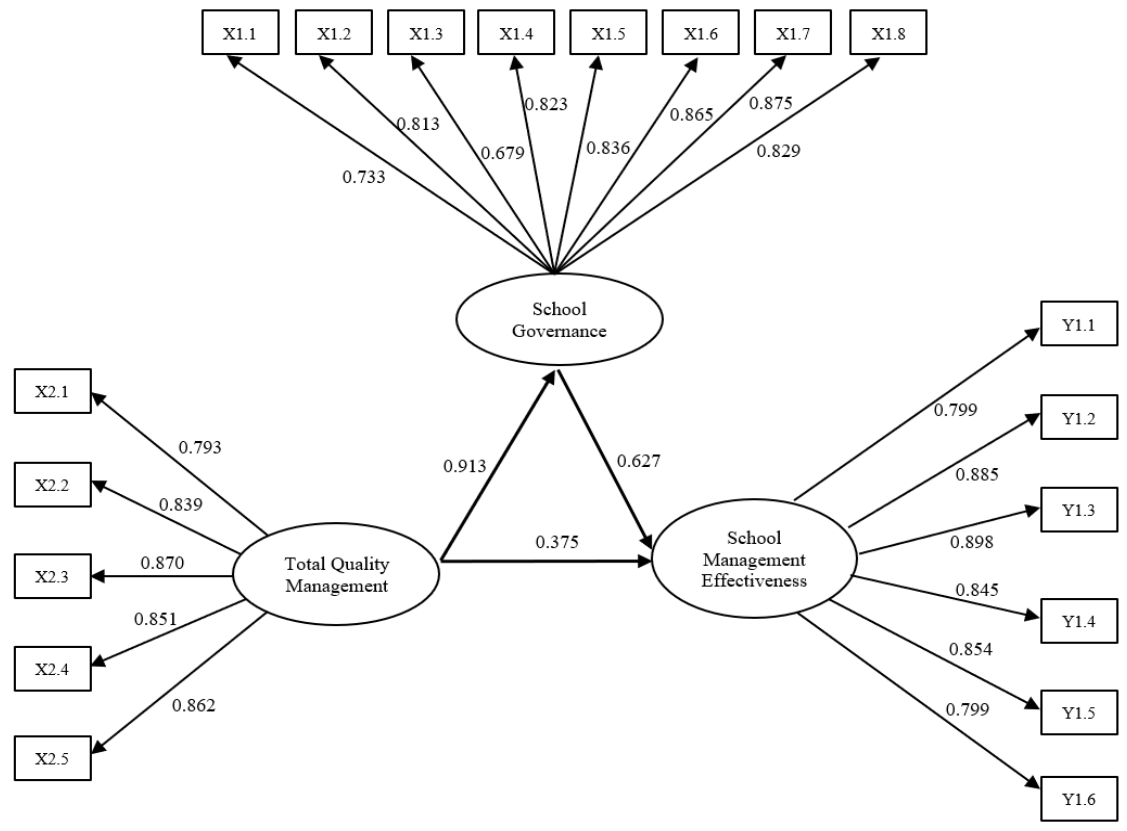

Figure 2. The result of structural equation modeling analysis 
To assess the model fit, estimates include the $\chi 2$-statistic, the goodness of fit index (GFI), root mean square error of approximation (RMSEA), comparative fit index (CFI), and normed fit index (NFI). The acceptable values to be $>0.9$ for the GFI and the NFI; suggest the value to be $>0.95$ for the CFI. The RMSEA values less than 0.08 indicate an acceptable range [79]. The goodness of fit results of the model is shown in Table 5. The model showed a good overall fit on almost all indices, CMIN $\chi 2^{1 / 4} 362.02$, RMSEA=0.055, $\mathrm{CFI}=0.978, \mathrm{NFI}=0.964$, and $\mathrm{GFI}=0.929$.

Table 5. The goodness of fit testing result

\begin{tabular}{cccc}
\hline Index & Cut off value & Result & Notes \\
\hline Chi-Square & Expected to below & 362.027 & Moderate \\
Probability & $\geq 0.05$ & 0.000 & Moderate \\
CMIN/df & $\leq 2$ & 2.586 & Moderate \\
RMSEA & $\leq 0.08$ & 0.055 & Good \\
CFI & $\geq 0.95$ & 0.978 & Good \\
NFI & $\geq 0.90$ & 0.964 & Good \\
GFI & $\geq 0.90$ & 0.929 & Good \\
AGFI & $\geq 0.90$ & 0.903 & Good \\
TLI & $\geq 0.90$ & 0.973 & Good \\
IFI & $\geq 0.90$ & 0.978 & Good \\
\hline
\end{tabular}

Table 6 presents the results of the hypothesis test that determined the relationship between each variable in the model. The results verify that Total Quality Management support positively influences School Governance $(\mathrm{H} 1$ : estimate $=0.913, \mathrm{p}<0.05$, R-squared=0.894). The positive relationship between School Governance and School Management Effectiveness is also supported by the results $(\mathrm{H} 2$ : estimate $=0.627$, $\mathrm{p}<0.05)$. The results further support the positive influence of Total Quality Management on School Management Effectiveness (H3: estimate=0.375, $\mathrm{p}<0.05$ ). The size of the influence of Total Quality Management and School Governance on School Management Effectiveness is shown by R-squared=0.936. The overall results confirm that School governance mediates the relationship of Total Quality Management on School Management Effectiveness, thereby supporting H4 with the indirect effect coefficient is 0.572.

Table 6. The hypothesis testing result

\begin{tabular}{cccccccc}
\hline & \multicolumn{1}{c}{ Relationship } & Estimate & S.E. & C.R. & P & R-Square \\
\hline School governance & $<---$ & Total quality management & 0.913 & 0.052 & 17.728 & $<0.05$ & 0.894 \\
School management effectiveness & $<---$ & School governance & 0.627 & 0.093 & 6.716 & $<0.05$ & 0.936 \\
School management effectiveness & $<---$ & Total quality management & 0.375 & 0.085 & 4.394 & $<0.05$ \\
School management effectiveness & $<---$ & Total quality management & 0.572 & & Indirect effect & \\
\hline
\end{tabular}

\subsection{Discussion}

The results of testing the first hypothesis resulted in the finding that the TQM variable had a positive and significant effect on SG. The positive coefficient value explains that the better the application of TQM in the vocational school-based enterprise, the better governance will be carried out by the school. The results of this conclusion are in line with research by Liantos \& Pamatmat [23]. TQM practices especially relating to leadership that focuses on stakeholders has a relationship with school leadership that is on school management and improving staff development. The relationship between TQM and SG revealed that in terms of improving the quality of schools, the role of the principal in implementing SG was very important in staff development, physical development, and student development. Strategic factors are leadership as vital in ensuring a successful implementation of TQM in an organization [80].

The results of the second hypothesis test produce findings that SG has a positive and significant effect on the latent variables of school management effectiveness. The positive coefficient value explains that the better the application of SG in the vocational school-based enterprise, the better its effectiveness. This finding is in line with research conducted by Bandur [34] and Volansky \& Friedman [41] which states that schools that implement the SG component will significantly improve teaching and learning processes and provide significant improvements, both improving education and learning achievement and increasing school effectiveness. SG can improve school effectiveness because schools that have implemented SG can effectively improve school performance because they have authority over the budget, personnel, and curriculum [38]. This authority is ultimately used as the power to implement changes that directly affect teaching and learning practices. The management of vocational schools in Indonesia requires improvements in line with the vision of Indonesian education. The vision and mission that exist in schools must be 
implemented and able to increase motivation, inspiration, and improve the quality and capacity of the school community and stakeholders [81].

The latent variable TQM has a positive and significant effect on the latent variable of school effectiveness. The results of this conclusion are in line with research conducted by Sadikoglu and Olcay [4]; Wani and Mehraj [49]; Venkatraman [51]; Peat, et al. [52]; and Hasan, et al. [66]. Based on research conducted by several researchers in several countries it was found that educational institutions need to adopt the philosophy of TQM to create school effectiveness which is demonstrated through better performance. The quality management practices in the field of education are able to make a good contribution to improving the quality of education and educational organizations.

The influence of TQM latent variables on latency variables of school effectiveness through the application of SG has never been examined statistically before. However, based on research by Liantos \& Pamatmat [23], TQM implementation, in general, influences school leadership because TQM practices have a relationship with staff development and school leadership in carrying out its role in SG. With the existence of SG practices, the principal's decision-making authority, school decision-making [68], as well as school board involvement can emerge to be able to create a better teaching and learning environment and student academic achievement that are indicators of effective schools [10, 45]. By combining the results of these studies it was implied that TQM had a role in creating the application of SG which could ultimately increase school effectiveness. The combined results of the study are in line with the results of this study which concluded that the latent variable TQM significantly influences the latent variable of school effectiveness through SG.

\section{CONCLUSION}

The strategy for increasing the effectiveness of the management of the vocational school-based enterprise, it can be concluded that the implementation of total quality management (TQM) has a significant positive effect on improving school governance (SG). The implementation of SG and TQM also has a significant positive effect on the effectiveness of the management of vocational school-based enterprises. The effectiveness of school management can be maximally implemented by increasing the implementation of school governance in schools by increasing the criteria for strong and firm leadership.

This research is still limited to vocational schools that have implemented School-Based Enterprise. Suggestions are taken into consideration for further research that is analyzing whether there are differences in strategies in increasing school effectiveness, both for schools with School-Based Enterprise status and for schools that have not or will be going to School-Based Enterprise.

\section{ACKNOWLEDGEMENTS}

The authors are grateful to Bogor Agricultural University, Indonesia and Directorate General of Vocational Education, Ministry of Education and Culture, Indonesia.

\section{REFERENCES}

[1] Central Bureau of Statistics (BPS), "Monthly Socio-Economic Data Report (in Bahasa)," Jakarta, 2020.

[2] A. S. M. Sohel-Uz-Zaman and U. Anjalin, "Implementing total quality management in education: compatibility and challenges," Open Journal of Social Sciences, vol. 4, no. 11, pp. 207-217, 2016.

[3] S. Sahney, D. K. Banwet, and S. Karunes, "Conceptualizing total quality management in higher education," The TQM Magazine, vol. 16, no. 2, pp. 145-159, 2004.

[4] E. Sadikoglu and H. Olcay, "The effects of total quality management practices on performance and the reasons of and the barriers to TQM practices in Turkey," Advances in Decision Sciences, vol. 2, pp. 1-17, 2014.

[5] R. Croker, F. Humphrey, and R. Wilson, "Defining instructional quality by employing the Total Quality Management (TQM) method: a research project," American Vocational Association Annual Conference, 1996, pp. 4-25.

[6] L. Lezotte, Creating the Total Quality Effective School. Washington DC: Effective Schools Products Ltd, 1992.

[7] R. Jaya, "Teori stakeholder," Account. Media, pp. 4-5, 2016.

[8] M. Majeca, "Good governance enhance the efficiency and effectiveness public spending-Sub Saharan countries," African Journal of Business Management, vol. 5, no. 11, pp. 3995-3999, 2011.

[9] W. Anderson, "Site-based management," in Smith, S.C., Piele, P.K., Eds. School Leadership: Handbook for Excellence in Student Learning. SAGE Publications, London, 2006, pp. 223-244.

[10] A. Bandur, "School-based management developments: challenges and impacts," Journal of Educational Administration, vol. 50, no. 6, pp. 845-873, 2012.

[11] T. Bush and D. Gamage, "Models of self-governance in schools: Australia and the United Kingdoms," International Journal of Educational Management, vol. 15, no. 1, pp. 39-44, 2001.

[12] D. Gamage, "School-based management: shared responsibility and quality in education," Education and Society, vol. 24, no. 1, pp. 27-43, 2006. 
[13] D. Hopkins, "What we have learnt from school improvement about taking educational reform to scale," School Effectiveness and School Improvement Research Policy Practice, vol. 4, no. 3, 2012.

[14] J. Hanaee, J. Handley, R. Rollins, and G. Worsdale, "An investigation of the role of leadership in the implementation of TQM in medical universities of Iran," in Proceedings of the 5th Quality Conference in the Middle East, 2011, pp. 156-164.

[15] K. Leithwood and C. Riehl, "What we know about successful school leadership?" in American Education Research Association Annual Conference, 2003, pp. 21-25.

[16] P. M. Senge, The Fifth Discipline: The Art and Practice of the Learning Organization. New York: Doubleday, 1999.

[17] K. H, Project Management: A systems approach to planning, scheduling and controlling, 8th ed. New York: John Wiley and Sons, 2003.

[18] C. Hoy, C. Jardine, and M. Wood, Improving Quality in Education. London: Falmer, 2005.

[19] A. de Grauwe, "Improving the quality of education through school-based management: learning from international experiences," International Review of Education, vol. 51, no. 4, pp. 269-287, 2005.

[20] M. Fullan, The New Meaning of Educational Change. Toronto: New Teachers College Press, 2007.

[21] F. Ulf, "Quality Education: the key role of teachers," Education International Work Paper, vol. 14, no. 1, 2004.

[22] M. Mukhopadhyay, Total Quality Management in Education. New Delhi: SAGE Publications, 2005.

[23] M. G. B. Llantos and F. V. Pamatmat, "Total quality management and school-based management practices of school principlas: their implications to school leadership and improvement," International Research Journal of Social Sciences, vol. 5, no. 8, pp. 1-7, 2016.

[24] Y. C. Cheng and M. M. C. Mok, "School-based management and paradigm shift in education: an empirical study," International Journal of Educational Management, vol. 21, no. 6, pp. 517-542, 2007.

[25] H. Lior and A. E. Nir, "School principals' leadership style and school outcomes," Journal of Educational Administration, vol. 52, no. 2, pp. 210-227, 2014.

[26] V. M. J. Robinson, C. A. Lloyd, and K. J. Rowe, "The impact of leadership on student outcomes: An analysis of the differential effects of leadership types," Educational Administration Quarterly, vol. 44, no. 5, pp. 635-667, 2008.

[27] J. O'Neil, "On tapping the power of school-based management," Educational Leadership, vol. 53, no. 4, pp. 67-70, 1995.

[28] A. Bergman, "Lessons for principals from site-based management," Educational Leadership, vol. 50, no. 1, pp. 48-51, 1992.

[29] K. Arar and A. Abu-Romi, "School-based management: Arab education system in Israel," J. Educ. Adm., vol. 54, no. 2, pp. 191-208, 2016.

[30] A. E. Nir, A. Ben David, R. Bogler, D. E. Inbar, and A. Zohar, "School autonomy and 21st century skills in the Israeli educational system: Discrepancies between the declarative and operational levels," International Journal of Educational Management, vol. 30, no. 7, pp. 1231-1246, 2016.

[31] A. E. Nir, "The impact of school-based management on supervision instructors' professional considerations," International Journal of Educational Management, vol. 17, no. 2, pp. 49-58, 2003.

[32] R. Allen, "Does School Autonomy Improve Educational Outcomes? Judging the Performance of Foundation Secondary Schools in England," DoQSS Working Papers. London: University of London, 2010.

[33] A. E. Nir and P. Piri, Self-Management of Schools: From Concept to Action. Jerusalem: Henrietta Szold Institute, 2007.

[34] A. Bandur, "A study of the implementation of school-based management in Flores primary schools in Indonesia," Thesis, University of Newcastle, 2008.

[35] F. Barrera-Osorio, T. Fasih, H. A. Patrinos, and L. Santibanez, Decentralized Decision-making in Schools: The Theory and Evidence on School-based Management. World Bank, 2009.

[36] K. Starr and C. Oakley, "Nurturing new leaders: teachers leading learning: the role of principals," Australian Educational Leader, vol. 30, no. 4, pp. 34-36, 2008.

[37] C. E. Domitrovich, et al., "How do school-based prevention programs impact teachers? Findings from a randomized trial of an integrated classroom management and social-emotional program," Prevention Science, vol. 17, no. 3, pp. 325-337, 2016.

[38] E. R. Odden and P. Wohlstetter, "Making school-based management right," Educational Leadership, vol. 52, no. 5, pp. 32-37, 1995.

[39] T.-A. Rodriguez and J. R. Slate, "Site-based management: a review of the literature," 2005. [Online]. Available: http://citeseerx.ist.psu.edu/viewdoc/download?doi=10.1.1.552.9447\&rep=rep1\&type=pdf.

[40] B. Caldwell, School-Based Management. Education Policy Series. UNESCO: International Academy of Education and International Institute for Educational Planning, 2005.

[41] A. Volansky and I. A. Friedman, School-based Management: An International Perspective. London: Routledge, 2003.

[42] A. Bandur and D. Gamage, "How did school councils in Indonesia improve teaching/learning environments and student achievements?" Journal of Applied Research in Higher Education, vol. 18, pp. 15-28, 2014.

[43] D. Gamage, Professional Development for Leaders and Managers of Self-Governing Schools. Dordrecht: Springer, 2006.

[44] D. Gamage and P. Sooksomchitra, "Decentralization and school-based management in Thailand," International Review of Education, vol. 50, no. 1, pp. 289-305, 2004.

[45] D. Gamage and J. Zajda, "Decentralization and school-based management: a comparative study of self-governing schools' models," Educational Practice and Theory, vol. 27, no. 2, pp. 35-58, 2009.

[46] J. Sabas and S. O. Mokaya, "The influence of governance systems on students' performance in public secondary schools in Karatu," International Journal of Science and Research (IJSR), vol. 5, no. 10, pp. 1595-1598, 2015. 
[47] S. M. Lo, H.-P. Shen, and J. C. Chen, "An integrated approach to project management using the Kano model and QFD: an empirical case study," Total Quality Management \& Business Excellence, vol. 28, no. 13, pp. 1-26, 2016.

[48] K. Leithwood, A. Harris, and D. Hopkins, "Seven strong claims about successful school leadership," School Leadership and Management, vol. 28, no. 1, pp. 27-42, 2008.

[49] I. A. Wani and H. K. Mehraj, "Total Quality Management in Education: An Analysis," International Journal of Humanities and Social Science Invention, vol. 3, no. 6, pp. 71-78, 2014.

[50] P. M. Terry, "Using total quality management principles to implement school-based management," International Conference of the International Association of Management, 1996, vol. 14, pp. 1-11.

[51] S. Venkatraman, "A framework for implementing TQM in higher education programs," Quality Assurance in Education, vol. 8, no. 1, pp. 103-131, 2007.

[52] M. Peat, C. E. Taylor, and S. Franklin, "Re-engineering of undergraduate science curricula to emphasize development of lifelong learning skills," Innovations in Education and Teaching International, vol. 42, pp. 135-146, 2005.

[53] J. V. Koch and J. L. Fisher, "Higher education and total quality management," Total Quality Management and Business Excellence, vol. 9, no. 8, pp. 659-668, 1998.

[54] W. Deming, "Total quality management in higher education," Management Services, vol. 35, pp. 18-20, 1993.

[55] M. Tribus, "Why not education: quality management in education," Journal for Quality and Participation, vol. 16, pp. 12-21, 1993.

[56] M. Peak, "TQM transform the classroom,” Management Review, vol. 84, no. 9, pp. 13-19, 1995.

[57] R. K. Michael, V. E. Sower, and J. Motwani, "A comprehensive model for implementing total quality management in higher education," Benchmarking for Quality Management \& Technology, vol. 4, no. 2, pp. 104-120, 1997.

[58] J. H and N. F, "Linkages between total quality management and the outcomes- based approach in an education environment," Quality in Higher Education, vol. 11, no. 3, pp. 251-260, 2005.

[59] K. A. Sharples, M. Slusher, and M. Swaim, "How TQM can work in education," Qualification Program, pp. 75-78, 1998.

[60] K. Barnett, J. McCormick, and R. Conners, "Transformational leadership: panacea, placebo or problem?" Journal of Educational Administration, vol. 39, no. 1, pp. 24-46, 2001.

[61] S. M. Widrick, E. Mergen, and D. Grant, "Measuring the dimensions of quality in higher education," Total Quality Management, vol. 13, no. 1, pp. 123-131, 2002.

[62] E. Hoyle, The Politics of School Management. London: Hodder and Stoughton, 1986.

[63] A. McMahon, A cultural perspective on school effectiveness, school improvement and teacher professional development. London: Continum, 2001.

[64] J. Oakland, Total Quality Management, 3rd ed. Amsterdam: Text with Cases, 2000.

[65] D. Summers, Quality. New Jersey: Pearson Prentice Hall, 2006.

[66] K. Hasan, et al., "Total quality management (TQM): implementation in primary education system of Bangladesh," International Journal of Research in Industrial Engineering, vol. 7, no. 3, pp. 370-380, 2018.

[67] M. Svensson and B. Klefsjö, "TQM-based self-assessment in the education sector: Experiences from a Swedish upper secondary school project," Quality Assurance in Education, vol. 14, no. 4, pp. 299-323, 2006.

[68] K. Arar and M. A. Nasra, "Linking school-based management and school effectiveness: the influence of self-based management, motivation and effectiveness in the Arab education system in Israel," Educational Management Administration \& Leadership, vol. 48, no. 1, pp. 186-204, 2018.

[69] R. L. Scheaffer, et al., Elementary Survey Sampling, 7th ed. Boston: Cengage Learning, 2011.

[70] B. Bergman and B. Klefsjö, Quality from Customer Needs to Customer Satisfaction. London and Studentlitteratur Lund: McGraw-Hill, 1994.

[71] L. Kennerfalk, Changes in organizational structure related to the implementation of a Total quality management strategy. Luleå: University of Technology, 1995.

[72] F. Hénard and A. Mitterle, Governance and quality guidelines in Higher Education. Paris: OECD, 2010.

[73] I. S. S. A., ISSA Guidelines on Good Governance. Geneva: Creative Commons Attribution-No. CommercialNoDerivs, 2013

[74] Đ. T. N. Quyên, "Developing university governance indicators and their weighting system using a modified Delphi method," Procedia-Social and Behavioral Sciences, 2014, vol. 141, pp. 828-833.

[75] P. Verma and S. Chabra, Application of pedagogical knowledge \& skills acquired in teacher training to school teachers of mathematics. New Delhi: NCERT, 1996.

[76] J. Scheerens, Improving school effectiveness: Fundamentals of Educational Planning. Paris: UNESCO, 2000.

[77] J. Dotchin and J. Oakland, "Theories and concepts in total quality management," Total Quality Management, vol. 3, no. 2, pp. 133-146, 2006.

[78] E. Sallis, Integrated Quality Management for Education (in Bahasa), (Trans: Ahmad Ali Riyadi). Yogyakarta: Ircisod, 2010.

[79] J. F. Hair, G. T. M. Hult, C. M. Ringle, and M. Sarstedt, Primer on Partial Least Square Structural Equation Modeling (PLS-SEM). Los Angeles: SAGE Publications, 2014.

[80] F. A. M. Al-Shabibi, "Total quality management performance in Omani small and medium enterprises (SMES)," Humanities \& Social Sciences Reviews, vol. 7, no. 2, pp. 45-47, 2019.

[81] S. F. Shodiq, et al., "Towards better management of private education in Indonesia: lessons learned from Muhammadiyah schools," Humanities \& Social Sciences Reviews, vol. 7, no. 2, pp. 146-155, 2019. 